Journal of Management and Bussines (JOMB)

Volume 1, Nomor 2, Desember 2019

p-ISSN : 2656-8918

e-ISSN: $2684-8317$

DOI : https://doi.org/10.31539/jomb.v1i2.677

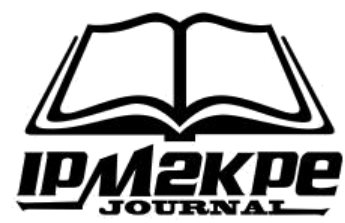

\title{
PENGARUH PROMOSI DAN SALURAN DISTRIBUSI TERHADAP KEPUASAN PELANGGAN
}

\author{
Nasruddin $^{1}$, Nurchayati ${ }^{2}$ \\ Universitas Bina Insan Lubuklinggau ${ }^{1,2}$ \\ nasruddin23101963@gmail.com ${ }^{1}$
}

\begin{abstract}
This study aims to determine the effect of promotion and distribution channels on customer satisfaction on the CV. Sinar Laut Baru Lubuklinggau. This study uses multiple regression, to find out how far the influence of independent variables on the dependent variable. The results of the study, the results of the t test calculation can be concluded that the Promotion (X1) has an effect on customer satisfaction (Y), showing the value of $t=4.503$ is greater than the value of the table (2.036). The results of test calculations that the distribution channel (X2) affect the Customer Satisfaction (Y), show the value of $t=4.312$ is greater than the value of the table (2.036). 3). The recapitulation of the Fcount test results obtained was 14.255> Ftable $=3.29$. Conclusions, jointly (simultaneously) promotion and Distribution Channels have a significant effect on Customer Satisfaction
\end{abstract}

Keywords: Promotion, Distribution Channels, Customer Satisfaction

\begin{abstract}
ABSTRAK
Penelitian ini bertujuan untuk mengetahui pengaruh promosi dan saluran distribusi terhadap kepuasan pelanggan pada CV. Sinar Laut Baru Kota Lubuklinggau. Penelitian ini menggunakan regresi berganda, untuk mengetahui seberapa jauh pengaruh independent variable terhadap dependent variable. Hasil penelitian, hasil perhitungan uji t dapat disimpulkan bahwa Promosi $\left(\mathrm{X}_{1}\right)$ berpengaruh terhadap kepuasan pelanggan $(\mathrm{Y})$, menunjukkan nilai $t_{\text {hitung }}=4,503$ lebih besar dari nilai $t_{\text {tabel }}(2,036)$. Hasil perhitungan uji t bahwa saluran distribusi $\left(\mathrm{X}_{2}\right)$ berpengaruh terhadap Kepuasan Pelanggan (Y), menunjukkan nilai $t_{\text {hitung }}=4,312$ lebih besar dari nilai $t_{\text {tabel }}(2,036)$. 3).

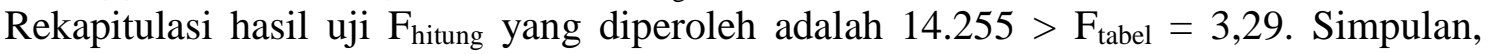
secara bersama-sama (simultan) promosi dan Saluran Distribusi memiliki pengaruh yang signifikan terhadap Kepuasan Pelanggan
\end{abstract}

Kata Kunci : Promosi, Saluran Distribusi, Kepuasan Pelanggan

\section{PENDAHULUAN}

Perekonomian di Indonesia yang semakin pesat dan berkembang memicu munculnya banyak perusahaan. Pertumbuhan ekonomi ini berlaku juga untuk wilayah Lubuklinggau. Lubuklinggau, sebagai salah satu kota di Sumatera Selatan memiliki posisi strategis sebagai kota perlintasan jalur tengah Sumatera yang membuat sektor 
perdagangan berkembang pesat. Perkembangan yang semakin baik tentu saja berdampak terhadap semakin banyaknya perusahaan yang berdiri baik bidang barang maupun jasa. Hal ini menuntut perusahaan untuk mampu bersaing dengan perusahaan lain agar dapat tetap bertahan bahkan semakin maju. Perusahaan harus selalu melakukan perkembangan dalam upaya untuk meningkatkan penjualan perusahaan serta memuaskan kebutuhan pelanggannya.

Pelanggan merupakan aset yang sangat penting bagi perusahaan. Dengan adanya pelanggan, perusahaan bisa tumbuh. Memiliki pelanggan loyal akan membuat perusahaan memiliki daya saing yang kuat di tengah ketatnya persaingan. Terciptanya kepuasan pelanggan dapat memberikan beberapa manfaat, diantaranya hubungan antara perusahaan dan pelanggan menjadi harmonis, memberikan dasar yang baik bagi pembelian ulang, membentuk suatu rekomendasi dari mulut ke mulut yang menguntungkan perusahaan. Salah satu cara yang dapat dilakukan oleh perusahaan dalam mempertahankan pelanggan adalah dengan meningkatkan promosinya.

Pada hakekatnya promosi adalah suatu bentuk komunikasi pemasaran. Yang dimaksud dengan komunikasi pemasaran adalah "Aktifitas pemasaran yang berusaha menyebarkan informasi, mempengaruhi atau membujuk, dan atau mengingatkan pasar sasaran atas perusahaan agar bersedia menerima, membeli, dan loyal pada produk yang ditawarkan oleh perusahaan yang bersangkutan (Tjiptono, 2008). Akhir-akhir ini, masalah yang dihadapi oleh hampir semua perusahaan adalah bagaimana mempromosikan produk mereka kepada konsumen dan meraih konsumen sebanyakbanyaknya serta menjaga agar mereka tetap menjadi pelanggan setia.

Saluran distribusi memegang peranan penting dalam suatu perusahaan. Menurut Tjiptono (2008) saluran distribusi adalah rute atau rangkaian perantara, baik yang dikelola pemasar maupun yang independen, dalam menyampaikan barang dari produsen ke konsumen. Dengan adanya saluran distribusi yang baik dapat menjamin ketersediaan produk, agar setiap saat dibutuhkan oleh pelanggan yang bersangkutan dapat diperoleh dengan mudah dan cepat. Kealpaan suatu perusahaan untuk dapat menyediakan produknya setiap saat dibutuhkan oleh pelanggan, akan menimbulkan konsekuensi bahwa loyalitas pelanggan terhadap merk produknya menurun. Seandainya kealpaan ini sering terjadi di suatu perusahaan, maka loyalitas pelanggan terhadap merk produk 
tertentu pada akhirnya akan semakin menurun dan kemungkinan pelanggan bisa berpindah pada merk produk yang lain.

Adanya kenyataan yang demikian ini, maka betapa pentingnya pemilihan yang tepat terhadap masalah saluran distribusi yang digunakan oleh perusahaan. Sebab apabila saluran distribusi yang digunakan ternyata menghambat kelancaran arus barang maka pada akhirnya hanya akan mempengaruhi kepuasan pelanggan terhadap produk itu sendiri.

CV. Sinar Laut Baru merupakan sebuah perusahaan di Kota Lubuklinggau yang bergerak dibidang distributor berbagai jenis produk dengan berbagai jenis merek seperti Bola Dunia, Bantan, Softex, Inaco dan Prochiz, dan masih banyak lagi merek serta produk lainnya. Perusahaan ini menyalurkan produknya ke seluruh wilayah Lubuklinggau dengan target penjualan ke toko-toko dan minimarket yang ada di Lubuklinggau. Pesaing dalam bisnis ini semakin banyak, sejalan dengan semakin berkembangnya perekonomian saat ini membuat banyak perusahaan yang mempunyai bisnis serupa dengan produk-produk yang cukup bersaing.

Menurunnya penjualan pada CV. Sinar Laut Baru Kota Lubuklinggau dikarenakan masih kurangnya sistem promosi yang dilakukan ke pelanggan, ini terlihat dari tingkat pembelian pelanggan ke perusahaan yang cenderung menurun. Selain itu, tenaga penjualan juga terkadang lupa mempromosikan produk-produk yang sedang diskon saat itu sehingga berkurangnya minat beli pelanggan. Dalam hal distribusi, berdasarkan pendapat pelanggan, terkadang produk yang dipesan terlambat sampai di lokasi pelanggan. Selain itu, stok barang sering kosongsehingga pelanggan harus menunggu dulu sampai barang tersedia. Hal ini berdampak terhadap berkurangnya kepuasan pelanggan terhadap perusahaan.

\section{LANDASAN TEORI}

\section{Kepuasan Pelanggan}

Menurut Daryanto dan Ismanto (2014) kepuasan pelanggan merupakan suatu penilaian emosional dari pelanggan setelah penggunaan suatu produk, dimana harapan dan kebutuhan terpenuhi. Menurut Irawan (Sudaryono, 2016), ada sepuluh prinsip kepuasan pelanggan yang harus diperhatikan untuk merebut hati mereka, yaitu: 
1. Memulai dengan percaya akan pentingnya kepuasan pelanggan, menanam kepuasan menuai laba.

2. Memilih pelanggan dengan benar untuk membangun kepuasan pelanggan.

3. Memahami harapan pelanggan, mengontrol harapan, dan menggali harapan pelanggan.

4. Mencari faktor-faktor yang mempengaruhi kepuasan pelanggan: faktor-faktor pendorong, kepuasan dimulai dari pabrik, dimensi kualitas pelayanan (tangible, reliability, responsitivenes, assurance, dan emphaty).

5. Faktor emosional (estetika, self expressive value dan brand personality) adalah faktor penting yang memengaruhi kepuasan pelanggan.

6. Pelanggan yang komplain adalah pelanggan yang loyal.

7. Garansi kepada pelanggan adalah lompatan yang besar dalam kepuasan konsumen atau pelanggan.

8. Mendengarkan suara pelanggan melalui pengukuran kepuasan pelanggan, memanfaatkan hasil riset kepuasan pelanggan dan performance importance mapping.

9. Peran karyawan (empowerment dan teamwork) sangat penting dalam upaya memuaskan konsumen atau pelanggan.

10. Kepemimpinan (peran pemimpin dalam kepuasan pelanggan) adalah teladan dalam kepuasan pelanggan.

Tahap menciptakan pelayanan dan kepuasan pelanggan adalah sebagai berikut (Sudaryono, 2016), 1) dengarkan dan perhatikan pelanggan, 2) tetapkan pelayanan yang terbaik, 3) tetapkan ukuran dan kinerja standar, 4) berikan perlindungan hak-hak karyawan, 5) latih karyawan untuk memberikan pelayanan yang istimewa, 6) gunakan teknologi yang memberikan pelayanan terbaik, 7) berikan hadiah bagi pelayanan terbaik. Menurut Daryanto dan Ismanto (2014) terdapat lima indikator utama kepuasan pelanggan, yaitu: 1) kualitas produk, 2) harga, 3) kualitas pelayanan, 4) faktor emosional, 5) biaya dan kemudahan

Faktor yang sering digunakan dalam mengevaluasi kepuasan terhadap suatu produk menurut Garvin dalam lovelock, Peppard dan Rowland (Tjiptono, 2008) antara lain meliputi:

1. Kinerja (performance) karakteristik operasi pokok dari produk inti yang dibeli.

2. Ciri-ciri atau keistimewaan tambahan. 
3. Keandalan (reliability), yaitu kemungkinan kecil akan mengalami kerusakan atau gagal dipakai.

4. Kesesuaian dengan spesifikasi, yaitu sejauh mana karakteristik desain dan operasi memenuhi standar-standar yang telah ditetapkan sebelumnya.

5. Kualitas yang dipersepsikan (perceived quality), yaitu citra dan reputasi produk serta tanggung jawab perusahaan terhadapnya.

\section{Promosi}

Menurut Hamdani (Sunyoto, 2014) promosi merupakan salah satu satu variabel dalam bauran pemasaran yang sangat penting dilaksanakan oleh perusahaan dalam memasarkan produk. Gitosudarmo (Sunyoto, 2014) mengatakan bahwa promosi merupakan kegiatan yang ditujukan untuk memengaruhi konsumen agar mereka dapat menjadi kenal akan produk yang ditawarkan oleh perusahaan kepada mereka dan kemudian mereka menjadi senang lalu membeli produk tersebut.

Tujuan utama dari promosi adalah menginformasikan, mempengaruhi, dan membujuk, serta mengingatkan pelanggan sasaran tentang perusahaan dan bauran pemasarannya (Tjiptono, 2008), 1) menginformasikan (informing), 2) membujuk pelanggan sasaran (persuading), 3) mengingatkan (reminding). Walker (Sunyoto, 2014) membagi lima metode promosi meliputi: 1) penjualan tatap muka (personal selling), 2) periklanan (advertising), 3) promosi penjualan (sales promotion), 4) publisitas (publicity), 5) hubungan masyarakat (public relation). Indikator promosi menurut Gitosudarmo (Sunyoto, 2014) yaitu:

1. Iklan, merupakan alat utama untuk memengaruhi.

2. Promosi Penjualan, merupakan kegiatan untuk menjajakan produk yang dipasarkan sedemikian rupa sehingga konsumen akan mudah untuk melihatnya.

3. Publikasi, merupakan cara yang biasa digunakan untuk membentuk pengaruh secara tidak langsung kepada konsumen agar mereka menjadi tahu dan menyenangi produk yang dipasarkan.

4. Personal Selling, merupakan kegiatan untuk melakukan kontak langsung dengan para calon konsumennya. 


\section{Saluran Distribusi}

Menurut Etzel (Sunyoto, 2014) saluran distribusi terdiri dari serangkaian lembaga yang melakukan semua kegiatan yang digunakan untuk menyalurkan produk dan status pemilikannya dari produsen ke konsumen akhir atau pemakai bisnis ( $A$ distribution channel consist of the set of people and firm involved in the flow onf title to a product as it moves from producer to ultimate customer or business user).

Sedangkan menurut Tjiptono (2008) saluran ditribusi adalah rute atau rangkaian perantara, baik yang dikelola pemasar maupun yang independen, dalam menyampaikan barang dari produsen ke konsumen. Adapun tujuan dari penggunaan saluran disrtibusi menurut Tjiptono (2008) adalah memanfaatkan tingkat kontak atau hubungan, pengalaman, spesialisasi, dan skala operasi mereka dalam menyebarluaskan produk sehingga dapat mencapai pasar sasaran secara efektif dan efisien.

Menurut Tjiptono (2008), ada beberapa metode untuk memilih alternatif strategi struktur saluran distribusi, yaitu: 1) postponement-Speculation theory, 2) goods approach, 3) financial Approach, 4) pertimbangan lain. Prosedur menentukan saluran distribusi menurut Sigit (Sunyoto, 2014) sebagai berikut:

1. Melakukan analisis terhadap produk yang akan dipasarkan untuk menentukan sifatsifat dan gunanya.

2. Menentukan sifat-sifat produk dan luasnya pasar.

3. Meninjau saluran-saluran distribusi yang sudah ada atau yang mungkin dapat digunakan.

4. Menilai masing-masing saluran dari sudut potensi volume penjualan, biaya yang layak dan laba yang wajar.

5. Melakukan market survey untuk mengetahui pendapat-pendapat pembeli dan perantara mengenai saluran distribusi yang dipergunakan oleh para pesaing.

6. Menentukan sifat dan luasnya kerjasama antara manufaktur dengan saluran-saluran distribusi yang akan digunakan.

7. Merumuskan bantuan-bantuan apa yang diberikan oleh manufaktur kepada penyalur-penyalur.

8. Melakukan penilaian secara kontinu terhadap saluran distribusi yang telah digunakan mengingat adanya perkembangan-perkembangan pasar. 


\section{METODE PENELITIAN}

Populasi dalam penelitian ini adalah pelanggan yang membeli produk-produk dari CV. Sinar Laut Baru Kota Lubuklinggau yang berjumlah 161 pelanggan. Sedangkan didapatlah sampel sebanyak 34,82 pelanggan dan dibulatkan menjadi 35 pelanggan.Teknik pengumpulan data yang dipergunakan dari penelitian ini adalah sebagai berikut: 1) observasi. Pada langkah ini yang dilakukan peneliti adalah dengan mengadakan pengamatan terhadap objek yang akan diteliti, yang ada kaitannya dengan pokok bahasan yang dikaji, 2) Kuesioner. Teknik pengumpulan datanya yaitu dengan cara membagikan kuesioner yang telah dipersiapkan kepada responden dalam hal ini pelanggan CV. Sinar Laut Baru Kota Lubuklinggau, 3) dokumentasi. Pengambilan data yang berasal dari literatur atau buku-buku yang berkaitan dengan pembahasan dalam penelitian ini. Teknik analisis menggunakan regresi linear berganda. Kemudian dilakukan Uji $\mathrm{F}$ untuk mengetahui pengaruh variabel bebas secara bersama-sama (simultan) terhadap variabel terikat.

\section{HASIL PENELITIAN}

\section{Hasil Uji Validitas dan Reliabilitas}

Tabel 1

Hasil Uji Validitas Variabel Promosi $\left(\mathrm{X}_{1}\right)$

\begin{tabular}{|c|c|c|c|c|}
\hline \multirow[b]{2}{*}{ No } & \multirow[b]{2}{*}{ Item } & \multirow[b]{2}{*}{$\mathrm{r}_{\text {hitung }}$} & \multirow{2}{*}{$\begin{array}{c}\mathrm{r}_{\text {tabel }} \\
\alpha=0,05 \\
\mathrm{n}=20\end{array}$} & \multirow[b]{2}{*}{ Keterangan } \\
\hline & & & & \\
\hline 1. & Pertanyaan 1 & 0,596 & 0,444 & Valid \\
\hline 2. & Pertanyaan 2 & 0,491 & 0,444 & Valid \\
\hline 3. & Pertanyaan 3 & 0,575 & 0,444 & Valid \\
\hline 4. & Pertanyaan 4 & 0,491 & 0,444 & Valid \\
\hline 5. & Pertanyaan 5 & 0,609 & 0,444 & Valid \\
\hline 6. & Pertanyaan 6 & 0,575 & 0,444 & Valid \\
\hline 7. & Pertanyaan 7 & 0,669 & 0,444 & Valid \\
\hline 8. & Pertanyaan 8 & 0,594 & 0,444 & Valid \\
\hline 9. & Pertanyaan 9 & 0,507 & 0,444 & Valid \\
\hline 10. & Pertanyaan 10 & 0,507 & 0,444 & Valid \\
\hline
\end{tabular}


Tabel 2

Hasil Uji Validitas Variabel Saluran Distribusi $\left(\mathbf{X}_{2}\right)$

\begin{tabular}{ccccc}
\hline No & Item & $\mathrm{r}_{\text {hitung }}$ & $\begin{array}{c}\mathrm{r}_{\text {tabel }} \\
\alpha=0,05 \\
\mathrm{n}=20\end{array}$ & Keterangan \\
\hline 1. & Pertanyaan 1 & 0.688 & 0,444 & Valid \\
\hline 2. & Pertanyaan 2 & 0.770 & 0,444 & Valid \\
\hline 3. & Pertanyaan 3 & 0.797 & 0,444 & Valid \\
\hline 4. & Pertanyaan 4 & 0.808 & 0,444 & Valid \\
\hline 5. & Pertanyaan 5 & 0.562 & 0,444 & Valid \\
\hline 6. & Pertanyaan 6 & 0.765 & 0,444 & Valid \\
\hline 7. & Pertanyaan 7 & 0.597 & 0,444 & Valid \\
\hline 8. & Pertanyaan 8 & 0.513 & 0,444 & Valid \\
\hline 9. & Pertanyaan 9 & 0.505 & 0,444 & Valid \\
\hline 10. & Pertanyaan 10 & 0.751 & 0,444 & Valid \\
\hline
\end{tabular}

Tabel 3

Hasil Uji Validitas Variabel Kepuasan Pelanggan (Y)

\begin{tabular}{|c|c|c|c|c|}
\hline No & Item & $\mathrm{r}_{\text {hitung }}$ & $\begin{array}{c}r_{\text {tabel }} \\
\alpha=0,05 \\
n=20\end{array}$ & Keterangan \\
\hline 1. & Pertanyaan 1 & 0,630 & 0,444 & Valid \\
\hline 2. & Pertanyaan 2 & 0,514 & 0,444 & Valid \\
\hline 3. & Pertanyaan 3 & 0,543 & 0,444 & Valid \\
\hline 4. & Pertanyaan 4 & 0,557 & 0,444 & Valid \\
\hline 5. & Pertanyaan 5 & 0,522 & 0,444 & Valid \\
\hline 6. & Pertanyaan 6 & 0,513 & 0,444 & Valid \\
\hline 7. & Pertanyaan 7 & 0,514 & 0,444 & Valid \\
\hline 8. & Pertanyaan 8 & 0,786 & 0,444 & Valid \\
\hline 9. & Pertanyaan 9 & 0,576 & 0,444 & Valid \\
\hline 10. & Pertanyaan 10 & 0,543 & 0,444 & Valid \\
\hline
\end{tabular}

Dari tabel diatas dapat dilihat bahwa hasil pengujian validitas instrumen menunjukkan bahwa seluruh pernyataan valid karena nilai $r_{\text {hitung }}$ lebih besar dari nilai $\mathrm{r}_{\text {tabel }}$ dan bernilai positif. 
Tabel 4

Hasil Uji Reabiilitas

\begin{tabular}{lccc}
\hline \multicolumn{1}{c}{$\begin{array}{c}\text { Variabel } \\
\text { Penelitian }\end{array}$} & $\begin{array}{c}\text { Nilai } \\
\text { Cronbach's } \\
\text { Alpha }\end{array}$ & Nilai r tabel & Keterangan \\
\hline Promosi $\left(\mathrm{X}_{1}\right)$ & 0,885 & 0,444 & Reliabel \\
\hline $\begin{array}{l}\text { Saluran } \\
\left.\text { Distribusi ( } \mathrm{X}_{2}\right)\end{array}$ & 0,921 & 0,444 & Reliabel \\
\hline $\begin{array}{l}\text { Kepuasan } \\
\text { Pelanggan ( } \mathrm{Y})\end{array}$ & 0,902 & 0,444 & Reliabel \\
\hline
\end{tabular}

Berdasarkan tabel diatas diketahui nilai Cronbach's Alpha untuk variabel promosi sebesar 0,885, jika dibandingkan dengan $\mathrm{r}_{\text {tabel }}$ maka hasil Cronbach's Alpha lebih besar dari $r_{\text {tabel}}$, yaitu $0,885>0,444$ dengan taraf signifikan 95\% $(\alpha=0,05), r_{\text {tabel }}$ dapat diperoleh dengan melihat tabel Product moment pada taraf signifikan 0,05\% diperoleh angka 0,444. Berarti angket/kuesioner variabel promosi adalah realibel dan semua pernyataan untuk variabel promosi dapat dipercaya dan dapat digunakan dalam penelitian.

Selanjutnya untuk variabel saluran distribusi, nilai Cronbach's Alpha sebesar 0,926, jika dibandingkan dengan $r_{\text {tabel }}$ maka hasil Cronbach's Alpha lebih besar dari $\mathrm{r}_{\text {tabel}}$, yaitu $0,926>0,444$ dengan taraf signifikan $95 \%(\alpha=0,05), \mathrm{r}_{\text {tabel }}$ dapat diperoleh dengan melihat tabel Product moment pada taraf signifikan 0,05\% diperoleh angka 0,444. Berarti angket/kuesioner variabel promosi adalah realibel dan semua pernyataan untuk variabel saluran distribusi dapat dipercaya dan dapat digunakan dalam penelitian.

Untuk variabel kepuasan pelanggan, nilai Cronbach's Alpha sebesar 0,905, jika dibandingkan dengan $\mathrm{r}_{\text {tabel }}$ maka hasil Cronbach's Alpha lebih besar dari $\mathrm{r}_{\text {tabel}}$, yaitu $0,905>0,444$ dengan taraf signifikan 95\% $(\alpha=0,05), r_{\text {tabel }}$ dapat diperoleh dengan melihat tabel Product moment pada taraf signifikan 0,05\% diperoleh angka 0,444. Berarti angket/kuesioner variabel kepuasan pelanggan adalah realibel dan semua pernyataan untuk variabel kepuasan pelanggan dapat dipercaya dan dapat digunakan dalam penelitian. 


\section{Hasil Uji Regresi Linier Berganda}

Tabel 5

Hasil Analisis Regresi Linier Berganda

Coefficients $^{\mathrm{a}}$

\begin{tabular}{lcccccc}
\hline & \multicolumn{2}{c}{$\begin{array}{c}\text { Unstandardized } \\
\text { Coefficients }\end{array}$} & $\begin{array}{l}\text { Standardized } \\
\text { Coefficients }\end{array}$ & & \\
\cline { 2 - 4 } Model & B & Error & Beta & t & Sig. \\
\cline { 2 - 4 } & 17.436 & 8.168 & & 2.135 & .041 \\
PROMOSI & .431 & .167 & .406 & 2.589 & .014 \\
SALURAN & .307 & .131 & .367 & 2.342 & .026 \\
DISTRIBUSI & & & & & & \\
\hline
\end{tabular}

a. Dependent Variable: KEPUASAN PELANGGAN

Dari hasil rekapitulasi hasil tegresi linier berganda di aias adapun persamaan regresi untuk mengestimasi variabel terikat dengan menggunakan seluruh variabel bebas adalah sebagai berikut :

$$
Y=17,436+0,431 X_{1}+0,307 X_{2}
$$

Hasil uji Regresi Linier Berganda menunjukkan bahwa :

1. Nilai (constant) menunjukkan nilai sebesar 17,436 artinya jika nilai variabel independent (Promosi dan Saluran Distribusi) nol maka nilai variabel dependen (Kepuasan Pelanggan) sebesar 17,436 dalam hal ini bila variabel independen naik atau berpengaruh dalam satu satuan, maka variabel bebas akan naik atau terpenuhi.

2. Nilai koefisien regresi variabel Promosi $\left(\mathrm{X}_{1}\right)$ terhadap variabel Kepuasan Pelanggan (Y) sebesar $b_{1}=0,431$ artinya jika Promosi $\left(\mathrm{X}_{1}\right)$ mengalami kenaikan satu satuan, maka akan mengalami peningkatan Kepuasan Pelanggan sebesar 0,431.

3. Nilai koefisien regresi variabel Saluran Distribusi $\left(\mathrm{X}_{2}\right)$ terhadap variabel Kepuasan Pelanggan (Y) sebesar $b_{2}=0,307$ artinya jika Saluran Distribusi $\left(\mathrm{X}_{2}\right)$ mengalami kenaikan satu satuan, maka akan mengalami peningkatan Kepuasan Pelanggan sebesar 0,307. 


\section{Hasil Uji Koefisien Determinasi $\left(\mathbf{R}^{2}\right)$}

Tabel 6

Hasil Analisis Regresi Determinan $\left(\mathbf{R}^{2}\right)$

Model Summary

\begin{tabular}{l|r|r|r|r}
\hline Model & $R$ & $R$ Square & $\begin{array}{c}\text { Adjusted R } \\
\text { Square }\end{array}$ & $\begin{array}{c}\text { Std. Error of the } \\
\text { Estimate }\end{array}$ \\
\hline 1 & $.686^{\mathrm{a}}$ & .471 & .438 & 1.689 \\
\hline
\end{tabular}

Sumber : Hasil Penelitian

Nilai koefisien determinan $\left(\mathrm{R}^{2}\right)$ yang diperoleh, adalah sebesar 0,471, dapat diartikan bahwa variasi perubahan nilai variabel terikat (Kepuasan Pelanggan) dapat dijelaskan oleh seluruh variabel bebas (Promosi dan Saluran Distribusi) secara bersamasama (simultan) sebesar 47,10\% dan sisanya sebesar 52,90\% dipengaruhi oleh variabelvariabel lain yang tidak dimasukkan dalam penelitian ini diantaranya pelayanan, harga, serta faktor lainnya.

\section{Hasil Uji F}

Dari analisa output regresi dapat diketahui nilai F seperti tabel berikut :

Tabel 7

Hasil Uji F

\section{ANOVA $^{\mathrm{b}}$}

\begin{tabular}{|c|c|c|c|c|c|c|}
\hline \multicolumn{2}{|c|}{ Model } & $\begin{array}{l}\text { Sum of } \\
\text { Squares }\end{array}$ & $d f$ & $\begin{array}{l}\text { Mean } \\
\text { Square }\end{array}$ & $\mathrm{F}$ & Sig. \\
\hline \multirow[t]{3}{*}{1} & Regression & 81.309 & 2 & 40.654 & 14.255 & .000 \\
\hline & Residual & 91.262 & 32 & 2.852 & & \\
\hline & Total & 172.571 & 34 & & & \\
\hline
\end{tabular}

a. Predictors: (Constant), SALURAN DISTRIBUSI, PROMOSI

b. Dependent Variable: KEPUASAN PELANGGAN 
Uji serentak/simultan (uji F) dilakukan untuk melihat pengaruh dari variabel bebas terhadap variabel terikat secara bersama. Berdasarkan rekapitulasi hasil uji regresi linier berganda, didapat bahwa nilai $\mathrm{F}_{\text {hitung }}$ yang diperoleh adalah 14,255 $>\mathrm{F}_{\text {tabel }}=3,29$ dan tingkat kemaknaan secara serentak sig $\mathrm{F}$ adalah 0,000. Nilai $\mathrm{F}_{\text {tabel }}$ diperoleh dengan perhitungan 35-2-1 = $32(32=3,29)$. Hal ini menunjukkan bahwa secara bersama-sama (simultan) variabel bebas penelitian (Promosi dan Saluran Distribusi) memiliki pengaruh signifikan terhadap variabel terikat (Kepuasan Pelanggan).

Jika $F_{\text {hitung }}>F_{\text {tabel }}$ maka Ho ditolak dan Ha diterima, sedangkan jika $F_{\text {hitung }}<F_{\text {tabel }}$ maka Ho diterima dan Ha ditolak. Dengan demikian hasil perhitungan diatas $\mathrm{F}_{\text {hitung }}$ sebesar 14,255 > $\mathrm{F}_{\text {tabel }}$ sebesar 3,29 maka Ho ditolak dan Ha diterima. Artinya terdapat pengaruh yang signifikan antara Promosi dan Saluran Distribusi terhadap Kepuasan Pelanggan pada CV. Sinar Laut Baru Kota Lubuklinggau. Hal ini juga membuktikan bahwa hipotesis ketiga penelitian ini yang berbunyi Promosi dan Saluran Distribusi berpengaruh terhadap Kepuasan Pelanggan pada CV. Sinar Laut Baru Kota Lubuklinggau.

\section{PEMBAHASAN}

Hasil penelitian menunjukkan bahwa ada pengaruh Promosi dan Saluran Distribusi terhadap Kepuasan Pelanggan Pada CV. Sinar Laut Baru Kota Lubuklinggau. Hal ini dapat dilihat dari persamaan hasil regresi sebagai berikut: $\mathrm{Y}=17,436+0,431 \mathrm{X}_{1}$ $+0,307 X_{2}$. Hasil uji Regresi Linear Berganda menunjukkan bahwa nilai (constant) menunjukan nilai sebesar 17,436 artinya jika nilai variabel independent (Promosi dan Saluran Distribusi) nol maka nilai variabel dependen (Kepuasan Pelanggan) sebesar 17,436 dalam hal ini bila variabel independen naik atau berpengaruh dalam satu satuan, maka variabel bebas akan naik atau terpenuhi. Nilai koefisien regresi variabel Promosi $\left(\mathrm{X}_{1}\right)$ terhadap variabel Kepuasan Pelanggan (Y) sebesar $\mathrm{b}_{1}=0,431$ artinya jika Promosi $\left(\mathrm{X}_{1}\right)$ mengalami kenaikan satu satuan, maka akan mengalami peningkatan Kepuasan Pelanggan sebesar 0,431. Nilai koefisien regresi variabel Saluran Distribusi $\left(\mathrm{X}_{2}\right)$ terhadap Kepuasan Pelanggan (Y) sebesar $b_{2}=0,307$ artinya jika Saluran Distribusi $\left(\mathrm{X}_{2}\right)$ mengalami kenaikan satu satuan, maka akan mengalami peningkatan Kepuasan Pelanggan sebesar 0,307 . 
Nilai koefisien determinan $\left(\mathrm{R}^{2}\right)$ yang diperoleh, adalah sebesar 0,471 , dapat diartikan bahwa variasi perubahan nilai variabel terikat (Kepuasan Pelanggan) dapat dijelaskan oleh seluruh variabel bebas (Promosi dan Saluran Distribusi) secara bersamasama (simultan) sebesar $47,10 \%$ dan sisanya sebesar 52,90\% dipengaruhi oleh variabelvariabel lain.

Uji serentak/simultan (uji F) dilakukan untuk melihat pengaruh dari variabel bebas terhadap variabel terikat secara bersama. Berdasarkan rekapitulasi hasil uji regresi linier berganda, didapat bahwa nilai $F_{\text {hitung yang diperoleh adalah } 14,255>F_{\text {tabel }}=3,29}$ dan tingkat kemaknaan secara serentak sig $\mathrm{F}$ adalah 0,000. Hal ini menunjukkan bahwa secara bersama-sama (simultan) variabel bebas penelitian (Promosi dan Saluran Distribusi) memiliki pengaruh yang signifikan terhadap variabel terikat (Kepuasan Pelanggan). Hasil uji serentak/simultan (uji F) ini juga membuktikan bahwa hipotesis ketiga penelitian ini yang berbunyi promosi dan saluran distribusi berpengaruh terhadap kepuasan pelanggan pada CV. Sinar Laut Baru Kota Lubuklinggau.

Secara umum pelaksanaan manajemen pemasaran sudah cukup baik dilakukan, hal ini ditandai dengan hasil pembahasan mengenai frekuensi jawaban dapat dlihat bahwa modus (angka yang sering muncul) adalah dengan skor 4 yaitu "setuju", yang artinya sebagian besar responden menyatakan perlu adanya Promosi yang dilakukan perusahaan dan peningkatan saluran distribusi. Hal ini konsisten dengan hasil penelitian Hendy Marta Andryanto, Saryadi, Widayanto (2013), hasil penelitian menunjukkan bahwa keempat variabel dependen mempunyai pengaruh yang positif dan signifikan terhadap variabel independen. Dari hasil analisis jalur kepuasan pelanggan mempunyai pengaruh yang positif dan signifikan terhadap loyalitas merek karena nilai $\mathrm{F}$ hitung lebih besar daripada nilai $\mathrm{F}$ tabel. Variabel yang dominan dalam mempengaruhi kepuasan pelanggan adalah kualitas produk karena memiliki nilai t hitung yang paling tinggi.

Tonny Sopan Sopian, Hariyani, H. Zakaria Ismail (2014), hasil analisis data dengan program SPSS didapat $F_{\text {hitung }}$ sebesar 7,794, dan untuk $F_{\text {tabel }}$ sebesar 2,70, yang berarti $F_{\text {hitung }}$ lebih besar daripada $F_{\text {tabel }}$ yaitu 7,794 > 2,70. Hal ini menjawab hipotesis, bahwa didapat pengaruh yang signifikan secara simultan dari Merek dan Saluran Distribusi Terhadap Kepuasan Pelanggan dan Loyalitas Pembelian. Dari hasil perhitungan jumlah pengaruh total (pengaruh langsung dan pengaruh tidak langsung) 
sebesar 0,485 atau 48,5\%. Artinya bahwa relatif besar dampak dari Merek dan Saluran Distribusi Terhadap Kepuasan Pelanggan dan Loyalitas Pembelian.

Hasil pengujian ini dapat dimaknai bahwa perlu adanya promosi dan peningkatan saluran distribusi sehingga dapat meningkatkan kepuasan pelanggan. Setelah disesuaikan dan dibandingkan dengan penelitian yang relevan bisa disimpulkan hasil penelitian ini menjelaskan bahwa Promosi dan Saluran Distribusi berpengaruh tehadap Kepuasan Pelanggan pada CV. Sinar Laut Baru Kota Lubuklinggau. Dimana setelah disesuaikan dari indikator iklan, promosi penjualan, publikasi dan personal selling. Dengan demikian diharapkan pimpinan CV. Sinar Laut Baru Kota Lubuklinggau harus mampu meningkatkan kegiatan promosi dalam memasarkan produknya seperti dengan memberikan diskon untuk pembelian tertentu, selain itu, karyawan CV. Sinar Laut Baru Kota Lubuklinggau juga perlu menjalin hubungan dengan pelanggan untuk mempromosikan produk-produk perusahaan. CV. Sinar Laut Baru Kota Lubuklinggau juga harus tepat waktu dalam pengiriman barang ke lokasi pelanggan, karena pengiriman barang yang tepat waktu dapat meningkatkan kepuasan pelanggan terhadap perusahaan.

\section{SIMPULAN}

Berdasarkan rekapitulasi hasil uji $\mathrm{F}_{\text {hitung }}$ yang diperoleh adalah 14,255 $>\mathrm{F}_{\text {tabel }}=$ 3,29. Hal ini menunjukkan bahwa secara bersama-sama (simultan) Promosi dan Saluran Distribusi memiliki pengaruh yang signifikan terhadap Kepuasan Pelanggan pada CV. Sinar Laut Baru Kota Lubuklinggau.

\section{DAFTAR PUSTAKA}

Daryanto, Ismanto Setyobudi. (2014). Konsumen dan Pelayanan Prima. Yogyakarta: Gava Media

Hendy Marta Andryanto, Saryadi, Widayanto. (2013). Pengaruh Kualitas Produk Dan Saluran Distribusi Terhadap Loyalitas Merek Diukur Melalui Kepuasan Pelanggan (Studi Kasus Pada Yamaha Mio Semarang Club). Jurnal. 2(4)

Sudaryono. (2016). Manajemen Pemasaran Teori \& Implementasi. Yogyakarta: Andi

Sunyoto, Danang. (2014). Dasar-Dasar Manajemen Pemasaran. Yogyakarta: CAPS (Center of Academy Publishing Service)

Tjiptono, Fandy. (2008). Strategi Pemasaran. Yogyakarta: Andi

Tonny, Hariyani, H. Zakaria Ismail. (2014). Pengaruh Merek, Saluran Distribusi Terhadap Kepuasan Pelanggan, Loyalitas Pembelian Produk Aqua (Studi Kasus Pada PT. Bintang Suryasindo Cabang Pangkalpinang Bangka). Jurnal, 1(1) 